\title{
Investigating the realist networks of the Chief Executive Officer of a multi-academy trust
}

DOI:

10.1080/00131911.2020.1721436

\section{Document Version}

Accepted author manuscript

Link to publication record in Manchester Research Explorer

\section{Citation for published version (APA):}

Hughes, B. C. (2020). Investigating the realist networks of the Chief Executive Officer of a multi-academy trust. Educational Review, 74(2), 243-262. https://doi.org/10.1080/00131911.2020.1721436

\section{Published in:}

Educational Review

\section{Citing this paper}

Please note that where the full-text provided on Manchester Research Explorer is the Author Accepted Manuscript or Proof version this may differ from the final Published version. If citing, it is advised that you check and use the publisher's definitive version.

\section{General rights}

Copyright and moral rights for the publications made accessible in the Research Explorer are retained by the authors and/or other copyright owners and it is a condition of accessing publications that users recognise and abide by the legal requirements associated with these rights.

\section{Takedown policy}

If you believe that this document breaches copyright please refer to the University of Manchester's Takedown Procedures [http://man.ac.uk/04Y6Bo] or contact uml.scholarlycommunications@manchester.ac.uk providing relevant details, so we can investigate your claim.

\section{OPEN ACCESS}




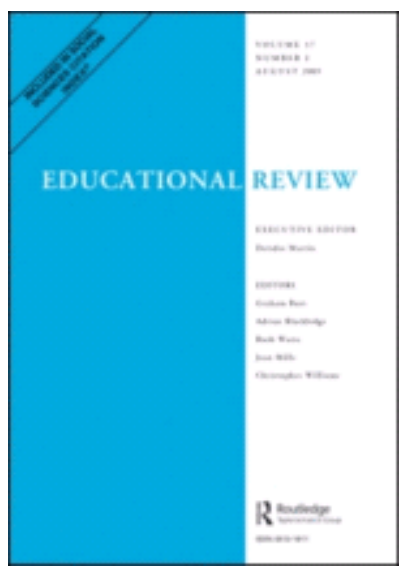

\section{Investigating the realist networks of the Chief Executive} Officer of a multi academy trust.

\begin{tabular}{|r|l|}
\hline Journal: & Educational Review \\
\hline Manuscript ID & Draft \\
\hline Manuscript Type: & Original Article \\
\hline Keywords: & realist networks, CEO, Multi academy trusts, governance \\
\hline \multicolumn{2}{|l}{} \\
\end{tabular}

\section{SCHOLARONE Manuscripts}




\title{
ERJ Anonymous \\ Investigating the realist networks of the Chief Executive Officer of a multi academy trust.
}

\begin{abstract}
The Chief Executive Officer (CEO) as corporate leader of a multi academy trust (MAT) is an emerging new construct of head teacher in England. Core to this position and practice is the construction and membership of specific networks that I conceptualise as realist. Such networks provide access to privileged policy influencers and corporate actors resulting in an important exchange relationship and reciprocity of resources. I examine these realist networks as a particular mode of governance, that is dialogic. The article reports on research from the larger Leadership of the Lawrence Trust Project, undertaken over a year using an ethnographic approach focusing on the case of KT Edwards, CEO of the Lawrence Trust. The article investigates Edwards' networks relationally, in so doing it examines the power exchanges that occur. The article uses empirical data to conclude that realist networks for Edwards are complex, dynamic sites of exchange, contingent upon trust, strength of ties and provide significant opportunities for entrepreneurial practices and dialogic governance.
\end{abstract}

Keywords: realist networks, CEO, multi academy trusts, governance

\section{Introduction}

This article reports on empirical research and conceptual analysis from the Leadership of the Lawrence Trust Project (LLTP) where I focus on the Chief Executive Officer, KT Edwards. Core to the purposes and practices of a MAT CEO is location within and 
operationalisation of policy networked connections and relational exchanges. Within the context of the Lawrence Trust such networks are proactively constructed or accessed by Edwards in order to facilitate privileged entry to powerful individuals and groups within government (e.g. Ministers and Civil Servants) and private interests in civil society (e.g. private sector business owners). Edwards' positioning within these interest groups as an educational expert and policy entrepreneur, signifies the plurality of actors dependent on each other in securing resources. This "exchange relationship" (Pierre 2009 p. 599) between the state and civic society as a form of governance aims to enhance the state's problem solving and governing capacity, policy implementation and delivery of services (Pierre, 2009). Within the policy studies field, research on networks is contested (Dowding, 2001), with debate amongst scholars concerning networks and their relationship to governance, (Rhodes 2002, Jessop, 2016), where state actors are expected to engage with civil society through meta-governance, rather than through hierarchic rule and state domination, (Hysing \& Lundberg 2016). Researchers have argued that networks traditionally have allowed policy to be developed through interactions with networked organisations and individuals, (Davies 2011; Jessop 2016). However, networks are problematised in terms of their ambiguous ontological position, (Börzel 1998), and for the lack of critical analysis in analysing their nature and structure, (Goodwin 2009). Moreover, the existing literatures "rarely, if ever, explore how actors understand the networks in which they work," (Rhodes 2002 p. 413). This article makes a significant contribution to the field: in using Edwards' case it identifies a new type of network as realist, through analysing their construction, membership, and impact; in so doing presents "more nuanced and qualified stories about particular institutional arrangements of state and civil interaction," (Hysing \& Lundberg 2016 p.22 original italics). 
Using Jessop's (2016) thinking on dialogic governance and Christopolous (2008) on relational networks allows both an original and empirical contribution. Firstly, I conceptualise Edwards' networks as realist networks which describe the specific, localised networks of the CEO of a MAT. It is the "everydayness" of Edwards' practices that are analysed identifying Edwards as a new form of school leader, policy entrepreneur, networker and broker within a highly corporatised public education system in England, Hughes (2019). Secondly, I utilise Jessop's (2016) thinking on governance in a novel way to present the dimensions of a realist network as a form of dialogic governance. Thirdly, in acknowledging that descriptive histories of policy networks often "find the obvious," (Dowding, 1995), I examine the unbounded dynamic nature of networks to analyse the instances of persuasion and negotiation between actors, examining the interplay between relational attributes, and levels of trust. I do this by deploying Christopoulos" (2008) thinking where I develop a novel heuristic to examine the relational exchanges between actors. Fourthly and empirically, I introduce Edwards as a corporate leader of a MAT, analysing data to explain how the CEO's realist networks are constructed and operated. I conclude that realist networks are localised and interdependent, functioning as a mode of governance.

\section{Conceptualizing the realist network}

Networks ${ }^{1}$ are:

... a set of relatively stable relationships which are of a non-hierarchical and interdependent nature linking to a variety of actors, who share common interests with regard to a policy, and who exchange resources to pursue these shared interests, (Börzel, 1998 p.254).

Networks comprise of institutional arrangements enabling the interaction between private and public actors. The term policy network is problematised however due to differing and 
contested conceptualisations (Dowding, 2001) and the "conceptual fog within the field" (of policy science) (Christopoulos 2008 p. 479). Börzel, (1998) describes policy networks as "a Babylonian variety of concepts and applications." Research within the policy science field is principally underpinned by two "schools" that of the "interest intermediation" school which sees "policy networks as a generic term for different forms of relationships between interest groups and the state," (Börzel, 1998 p. 255). Alternatively, the "governance school" (Jessop, 2016) describes a policy network as a continuing interaction between the state and civic society recognising the plurality of actors from the state, market and civic society. It is these governance structures that I use in conceptualising MAT CEO realist networks. I conceive realist networks both as a trope with a loose, bounded structure and as an analytical tool. They are realist because they are localised, self-proclaimed, and familiar reflecting day to day practices of the CEO. Such networks offer a sense of intimacy, often describing routine events, the nature of reality and bounded, observed cultural practices, (van Maanen, 2011). The return for network actors is the (real or symbolic) policy influence, securing internal co-operation and resources, attracting new members and seeking out opportunities for further influence.

Within the field of education, Ball, Junemann and Santori, (2017), have used policy networks as an analytical tool. Such studies have taken a macro level approach investigating global educational policy mobilities mapping private sector involvement in education. Adopting network ethnography as method, Ball et al (2017) researched the fluidity and mobilities of people, capital, organisations and ideas, presenting them as flat structures identifying linkages with individuals, organisations, and policy. Conversely, Goodwin (2009) argues that networks are not flat horizontal structures but have the potential for a hierarchical dimension based on the differentiated distribution of the 
capacities and resources amongst members. He suggests a network "hegemon" may exist responsible for recruitment, investing networks with authority, setting terms of reference. The hegemon can be identified by powers of decision making or agenda setting and selection (or exclusion) or control over information (Goodwin, 2009 p. 683). The hegemon thus adds to the "layers" of the network.

I now turn to introducing my conceptualisation of realist networks linking to a specific form of governance that of dialogic governance described by Jessop (2016).

\section{Dialogic governance and the realist network}

Hallmarks of neoliberal governance are the privatisation of the public sector, outsourcing, public-private partnerships with the aim of improved efficiency. The neoliberal ideology of the "fetishistic turn to the market" (Jessop, 2016 p. 165) and the call for leaner government resulted in the integration of community organisations and social movements into policy both in UK and internationally (Hysing \& Lundberg, 2016). In England this intensification was particularly prevalent under New Labour (1997-2010) with the focus on networks, interagency collaboration and partnerships. Triantafillou (2004 p. 489) calls this process "rearticulating our understanding of government and authority..." This rearticulation from government to governance has been well documented both in the UK, (Jessop, 2016, Rhodes 2002), and internationally, (Hysing \& Lundberg, 2016) with Rhodes (1997 p.17) suggesting that the "hollowed out-state" describes the process of the loss of central function. Others contest this (Jessop 2016), recognising that the neoliberal project of privatisation, bypassing local authorities with the increased use of special purpose bodies and consultants (Gunter and Mills, 2017) has in effect strengthened the regulatory capacity of the state. Rather, network governance is seen as a specific form of rule: that of "governing from a distance through the norms of agency, efficiency and 
accountability," (Triantafillou, 2004 p. 489). Jessop (2016) takes this forward arguing that "different modalities of state power" operate. In deploying Jessop's (2016) thinking on modes of governance and the role of networks helps to explain the interplay between networks, the market and governance. For Jessop (2016) governance refers to:

...mechanisms and strategies of coordination in the face of complex reciprocal interdependence amongst operationally autonomous actors, organisations and functional systems. (Jessop, 2016 p.166).

Underpinning this definition is the existence of "operationally autonomous actors" which coalesce around notions of reciprocal interdependence. Governance mechanisms and practices range from "international and supranational regimes to regional public-private partnerships to more localised networks of power and decision-making," (Jessop, 2016 p. 166). It is these "localised networks of power" I call realist networks that are the focus of this article. Table 1 shows the dimensions of the realist network based on Jessop (2016) in identifying their structure, characteristics and practice.

Table 1. Dimensions of the realist network Table 1 here

Realist networks are localised, often non-hierarchical, although at certain times a hegemon may exist, (Goodwin, 2009). They are interdependent and "self-organising... not governed by universal rules of procedures," (Triantafillou, 2004 p. 499). They are typified by rational consensual actions achieved through negotiation, characterised by their dynamic nature responding to external changes (Jessop 2016), such as: economic, ideological, knowledge and institutional. In practice, realist networks whilst fluid, are built around mutually beneficial activities through the exchange and sharing of resources. 
They operate non-competitively in what Jessop (2016) calls a dialogic rather than monologic mode, relying on informal and formal resource exchanges between government and non-government actors.

\section{Realist networks and their relational attributes}

While describing the structure, characteristics and practice of the realist network is useful, this identification has "limited potential" (Dowding, 2001 p. 89), so there is a need beyond structural representation to understand these networks through the actor's own constructions of them: that is to analyse the relationality of the realist network. Rhodes, (2002) in arguing for such an approach, emphasises the importance of policy networks being enacted by individuals, whose beliefs and actions are "not determined by their objective position within the network, but rather how their beliefs and actions construct the nature of the network," (Rhodes, 2002 p. 400). Therefore, in identifying how the networks of the CEO of a MAT are constructed, I am able to chart the relational dimensions, their complexities and the inter-relationships of actors. To do this I use thinking by Christopoulos (2008) to develop a framework to read data. Table 2 depicts the relational elements of the realist network based on the following criteria: conditions of membership, extent of representation (from "limited" to "unknown"), the nature of network ties, and locus of authority. I explain each of these below.

\section{Table 2 here}

Table 2: Relational attributes of realist networks

The conditions of membership are dictated by the nature and structure of the network. For example, membership of emerging realist networks is selective evolving over time where levels of trust may be low until clear goals and outcomes are agreed. 
Conversely, a local hegemonic network might limit membership based on its structure and purpose, such as a charitable foundation. Membership of other networks such as those relating to the state is fluid because membership is by invitation for participation in projects or for policy implementation.

I posit that network representation is the extent to which the network is represented by actors. Members can represent the network in a wide range of settings to more limited instances depending on goals. Network ties can be extensive because of network imbrication. Ties depicted in realist networks clearly do not have the same strength or value, however "the stronger the ties the higher the trust." (Christopoulos, 2008 p. 477). These ties act as links bonding the actors together, however within different realist networks actors are unlikely to have the same status or access to resources and maintaining ties "entails costs," (Christopoulos, 2008 p. 477). Integral ties are those which are intrinsic to the network, reciprocal ties are those which are complementary and corelative. Derivative ties are those drawn from an underlying "other party" (e.g. state actors). Granovetter (1973) assumes ties to be symmetrical and positive; the strength being determined by the amount of time, emotional intensity, mutual sharing and reciprocity that exist where strength, paradoxically, can be manifest in so-called weak ties. Weak ties for Granovetter (1973) are determined by time spent and similarities with other actors which can be cohesive. Granovetter (1973) draws attention to the importance of an individual with several weak ties as they "are best placed to diffuse a difficult innovation," and are "indispensable to their integration into communities" (Granovetter, 1973 p. 1378). In the unknown (or unacknowledged) networks the nature of ties remains indeterminate.

Locus of authority can be determined by the existence of a hegemon where the realist network has been constructed by a particular actor, setting the terms of reference 
and deciding on the extent to which resources are utilised, (Goodwin, 2009). Similarly, Christopolous (2006) identifies the hegemon as a policy entrepreneur, who controls information, attempts to influence others, seizing opportunities, often taking on a brokerage role within the network. In these realist networks ties can be weak or strong. Heterarchic control in a particular network has reciprocal strong ties, closed membership bound by professional frameworks, for example in a charitable foundation. Here the levels of trust between members is high because of the mutual emotional investment.

\section{The emerging position of the MAT CEO}

Realistic networks are an important way of conceptualising public services and in particular the reform of public education because they enable the focus to be put onto the individual CEO in ways that demonstrate the dialogic and relational dynamics of their position. Study of CEO roles in education policy research is limited, particularly of elite or corporate networks, (Au \& Ferrare, 2015), so there is a need to research their nature and construction. The emerging position of the CEO is rooted in education reform which has been subjected to the pervasive influence of corporatisation, both in England, (Courtney, 2016) and internationally (Gunter, Hall \& Apple, 2016). Integral to the corporatisation of schools is that the corporate model of organisation is applied to public education to maximise profit (Saltman, 2010). Corporatisation is a process whereby corporate ideologies penetrate education through the use of corporate language, corporate practices such as the commodification of leadership, efficiency, competition, branding, the use of corporate management models specifically relating to performance management, take overs, outsourcing (Courtney, 2016), and the use of consultants (see Gunter \& Mills, 2017). Education is a huge untapped market where big business is directly involved in the running of schools, (for example Edison Learning in the US, and 
Harris Academies in England). Schools have become enclaves of commercial activity, accordingly, "the corporatisation of public schools is an expression of neoliberal capitalism," (Saltman, 2010 p. 164). With the privileging of business practices the emergence of new corporate actors in schools in England has occurred where the professional identities of headteachers have been reconstructed and reconceptualised (Courtney, 2015a). This reconceptualization has led to headteachers being exposed to and involved with networks which comprise of "complex reciprocal interdependence" amongst “operationally autonomous actors," (Jessop, 2016 p.166). Such networks facilitate dialogic interaction (either tacit or explicit) including the exchange and sharing of resources, participating in mutually beneficial projects and building on interdependencies.

The legislative framework for this reconstruction of heads from the traditional lead professional role (Grace 1995) into a reworking of the moral and inspirational Victorian headmaster as the visioning chief executive and corporate entrepreneur position originated in the 1988 Educational Reform Act. The act reasserted government central control over education through the introduction of a national curriculum, national testing regimes and parental choice whilst devolving financial management from LAs to schools, requiring heads to become effective managers. Hartley (2018 p. xvii) explains the actualisation of the neoliberal project thus:

The mandarins and marketeers had cut a deal: more power for central government mandarins to hold the reins of curriculum and pedagogy; more power for the neoliberal policy makers to side-line elected local government officials...

What is integral to such accounts is that over the next thirty years, the "fracturing" of existing school structures created an assortment of education service providers: over 
seventy school types now exist in England, (Courtney, 2015b), resulting in a diversity of provision and a re-articulation of headship. Policy goals during the period have included increasing efficiency, raising educational standards and expanding choice and diversity (West \& Bailey, 2013). New Labour's (1997 - 2010) city academies programme launched in 2001 for example sought expertise and financial backing (up to $£ 2$ million) from local business sponsors to support school improvement in poor performing urban schools. These academies were set up as charitable trusts funded by central government lying outside the control of LAs. Headteachers were reconceptualised principally as managers responsible for school improvement and efficiency. The academies programme under the Conservative Coalition Government (2010-2015) accelerated the conversion of schools to become academies through the 2010 Education Act and the subsequent publication of The Importance of Teaching (2010) White Paper which articulated a vision of "rapidly expanding the academies programme" (DfE, 2010 p. 54). The emphasis focussed on new providers such as sponsors from business, charities and faith establishments entering the state system, a relaxation of the pay structures of teachers and accelerating the process whereby outstanding schools could become academies. This vision of a system of independent non fee-paying state schools "was more radical and extensive than anything that has gone before," (Coldron, Crawford, Jones, \& Simkins, 2014).

With the Conservative government's (2015 onwards) White Paper Excellence Everywhere (DfE, 2016), favouring a Self-Improving School-led System (DfE, 2016; Greany, 2018), the expectation was that all schools were to become academies with the preferred organisational structure being multi-academy trusts. MATs comprise groups of independent non-fee-paying schools with charitable trust status. Their legal foundation is that of a company limited by guarantee regulated by a Principal Regulator: The Secretary of State and directly funded by central government. In September 2018 there were 1525 
MATs operating in England, a fourfold increase since 2011, (DfE, 2018a). MATs vary in size: a middle-sized MAT for example comprises between 6-10 schools. Some of the largest MATs such as the Academies Enterprise Trust oversees 62 schools; (DfE, 2018). Headteachers now "repurposed as CEOs," (Courtney, 2015a p. 216) have become part of the leadership industry, they are highly mobile, intervening in schools, undertaking school improvement commissions and engaging as policy entrepreneurs in a complex policy landscape. The position demands much, including interactions with corporate and policy elites, direct interface with the market, and constructing, occupying and maintaining a variety of realist networks. To understand the nature and relationality of these networks empirical work is needed to determine how they are constructed, and the extent of instances of persuasion and negotiation.

\section{The Study: Methodology and Methods}

Edwards is the CEO of a middle-sized MAT, comprising eight schools (including a teaching school) ${ }^{3}$ covering a wide geographical region. He became the CEO in 2014 having previously been a headteacher for over a decade. Edwards locates himself beyond the Lawrence Trust through holding non-executive board positions on a regional (noneducational) trust, and a local charitable trust. He is chair of a national foundation (New Start - a pseudonym) with available funds of $£ 60$ million p.a. (New Start website accessed 8/8/18) Many of his networks lie beyond education where he promotes the Lawrence Trust, secures funding, developing business connections.

Edwards as a MAT CEO is an appropriate case subject for this study because the CEO position is an emerging role that is being scoped and scripted by those doing the job; this will establish the meaning and conduct of the role for at least a decade. Using realist networks as a trope illuminates the practice of the CEO whose inter-relationships 
and interdependencies are signified by diverse interactions with the market and other localised influential actors.

The methodological approach of the LLTP is located in an established qualitative tradition of case studies of single schools (Kulz 2017; Salokangas \& Ainscow, 2018) and those of individual headteachers (or principals) such as Wolcott (2003). The single case whilst not claiming any generalities remains particular, the implications of study are broad, (Wolcott, 1995). I sought to investigate the "complex specificness" (Geertz, 1973 p. 26) where the "effective story should be specific and circumstantial," (Wolcott, 1995 p. 174). The LLTP is micro ethnography concerned with "the local and situated ecology" of Edwards' operations, (Garcez, 2017 p. 435). My role as a former headteacher allowed degrees of cultural sharing where I adopted the position of the "professional stranger," Agar (1980). I observed Edwards in situ, conducting interviews over a twelve-month period and shadowing him. Data were gathered in their naturalistic setting framed by "methodological openness and flexibility" (McCann \& Ward, 2012 p. 43). Such approaches accommodate tensions between the design of research project with the reality of unexpected connections, mutations, as they emerge, building trust, (McCann \& Ward, 2012).

Data were gathered from sustained observations in the field and recorded as fieldwork notes (FWN). These were constructed using Spradley's (1980 p. 78) checklist and recorded at five-minute intervals. Whilst I observed I remained as unobtrusive as possible, writing field notes in situ yet recognizing the importance of "thick description" (Geertz, 1973), noting that:
“...capturing members' words alone is not enough for ethnography... Good ethnographies reflect tacit knowledge, the largely unarticulated, contextual understanding that is often manifested in nods, silences, humour, and naughty nuances.” (Altheide and Johnson, 1998 p. 403). 
Such "tacit knowledge" was acquired from both shadowing Edwards and through informal conversations with him. These were unstructured exchanges providing rich data recorded as fieldwork notes (FWN). Shadowing Edwards, (see Tulowitzki, 2019 on shadowing school principals) was deployed as a distinct methodological approach. Four semi-structured interviews took place over the period. The first focussed on Edwards' career (CI). The second on Edwards' values and vision (BPI), the third on the structure of the MAT (STRI). The fourth focussed on Edwards' networks (NWI). Transcriptions were member checked. Interview data was analysed through identifying key themes using NVivo software. This process was iterative, enabling analysis of Edwards' identified networks and his role within them. From the data names, and businesses mentioned were extracted identifying any connections between them. These data then became the subject of internet searches.

Applying the three dimensions of realist networks in table 1 to read data I was able to identify Edwards' networks practising dialogic governance. Reading the data through the heuristic depicted in table 2, using (Christopolous' 2008) enabled a more critical analysis of the realist network relations including conditions of membership, network representation, the nature of the ties, and the locus of authority. I addressed questions of trustworthiness through documentary analysis (Fitzgerald 2012) to corroborate data gathered in the field. The BERA (2018) ethical guidelines were used where all references to the trust and personnel were anonymised and data encrypted. Edwards' realist networks are of his own telling, reflecting "authenticity of the cultural representation conveyed" (Van Maanen, 2011 p. 45).

\section{Edwards' realist networks. identification and construction}

The research identified Edwards' five realist networks. 
- a local network - The Lawrence Trust;

- a regional network - The Youth Connect Foundation supporting young people with training, sport and personal development;

- a national network - New Start which constitutes a charitable trust funding sports facilities for local communities;

- The State including local government links;

- Emerging networks - the Goldfinch Trust - a health trust; and Project East an emerging network overseas.

The identification of these networks does not preclude the existence of others unacknowledged by Edwards, no data emerged during the project of the existence of any other network (including social networks). Reading the data using my dimensions of realist networks allows an analysis of their structure, characteristics and practice. Edwards' networks are "realist" in that it is the self-proclaimed, familiar "everydayness," of the nature of their operations, and their localised topography, reflecting the practices of the CEO. Membership of Edwards' realist networks are enduring, constructed from long term professional relationships, commercial ties, and personal links some constructed over a period of many years. Membership of the LT network reflects members with executive, commercial, and corporate backgrounds, including a Chief Operating Officer of a regional company, the CEO and the Managing Director of a large multinational (a PLC), and a national media outlet. Several members enjoy direct connections with colleagues from Edwards' Youth Connect network. These interconnections are mutually beneficial and consensual enabling dialogic governance. Membership of The Youth Connect network consists of an international corporation and its group managing director, the CEO of a highly successful property business, two professional sports people (both former students of the Lawrence Trust), and a TV 
personality. Edwards' networks reveal a diverse set of actors who "catalyses philanthropy and business on the delivery of education services" reconfiguring and disseminating "a particular set of policy discourses," (Ball \& Junemann, 2012 p. 9). Each network is the site of ideological and social cohesion, membership is fluid where careers are constructed within them (Ball \& Junemann, 2012). Edwards' realist networks are characterised by their reflexive nature, their responsiveness and interdependence. The LT network for example is a self-organised and localised network with Edwards as the hegemon, thus its structure is more hierarchical than in other networks such as Youth Connect where he is a board member. The pluralistic heterarchical model exists across three of Edwards' networks, for example in the Youth Connect network:

...sitting on that Board you have people like [TV personality], [ex professional footballer], [CE of national business] big hitters who see me in the same light because we all don't have a hierarchy. (NWI 17/4/18).

In constructing his realist networks, Edwards shrewdly considers micro-political contexts:

...it's about understanding the politics of each area, I understand the politics of four local authorities, the politics of the education departments, the newspaper politics, and the union politics and I have to have all of those fairly well nailed when we are making decisions about things. (STRI $11 / 9 / 18)$.

This understanding informs decisions and enhances agency. Edwards recognises the value and rewards gained through membership. Edwards' realist networks are constructed over time with Edwards judiciously seeking out opportunities and responding strategically and importunately: 
My networks are based on networks I have developed with different stakeholders... as we have moved to a school, I spend a lot of time working with local councillors, key community leaders, people who make a difference... Each one of those becomes a contact, ...the local networks develop into national networks. So, I know some key significant individuals through the boards I sit on, (NWI 17/4/18).

Edwards' networks extend and interrelate giving him political representation in private interest organisations; such representation leads to other membership opportunities.

\section{Edwards' realist networks and dialogic governance.}

Edwards' realist networks allow for dialogic governance. In utilising Jessop's (2016) thinking on dialogic governance each have "reflexive" characteristics, redefining goals and negotiating in the light of changing circumstances. Structurally Edwards' networks are self-organised, particularly the Lawrence Trust, the State and Emerging networks. He cultivates network actors spending time with key individuals which provide other opportunities thus enabling dialogic governance either tacitly or explicitly (Jessop, 2016), whilst remaining operationally autonomous:

I spend time with his Chief Operating Officer who then put me on the [name] Board, then I have influence across the city region... so I can ring up the head of [large regional business] and other people and say we have got $\mathrm{X}$ and $\mathrm{Y}$ going on what do you think? (NWI, 17/4/18).

Using his local and regional contacts, Edwards gains access to powerful policy makers: dinner with [name] (Secretary State for Education) for example who is "a big friend of my ex-chairman," (NWI 17/4/18). Within Edwards' networks it is clear that dialogic governance is present through sharing resources, participation in joint projects using a pluralistic heterarchic structure. However presenting Edwards' networks as a form of 
dialogic governance is rather "finding the obvious," Dowding (2001 p. 89), therefore I now analyse these relationally.

\section{Network relationships: membership, representation, ties and locus of authority Utilising Christopoulos' (2008) thinking, through the use of the heuristic in Table 2 allows an analysis of the relational elements of Edwards' networks which includes conditions of membership, representation, the strength of ties, and the locus of authority. I examine each individually.}

Membership: The conditions of membership of each of the networks vary within the LT network, participation is selective, with Edwards deciding on the conditions of membership. For example, he interviews all potential trustees and governors himself as part of their selection process; his senior team surreptitiously grade all potential staff who attend the Trust's annual recruitment morning. Those awarded a top grade during their visit are guaranteed an interview (FWN). The conditions of membership within his Youth Connect and New Start network, are tightly controlled by the organisations themselves. Within his emerging networks such as the Goldfinch Trust where membership is selective, Edwards' involvement has "already started to bring things into our schools...one of their staff is one of our governors," (NWI, 17/4/18).

It is with the State realist network that Edwards enjoys fluidity in terms of his membership in different collaborations established at different times and for different reasons, for example, Edwards' attendance at The House of Commons Select Committee (2018); advising Ofsted, and with his involvement with New Labour presenting to the Prime Minister: 
I did work at government level so nationally I was on advisory groups, so I was on the [name] Committee a few years ago... I presented in Downing Street. (NWI, 17/4/18)

He travelled overseas at the invitation of the National College of School Leadership ${ }^{6}$ researching leadership programmes: "I had not been a headteacher that long, so I was very flattered to be asked," (NWI, 17/4/18). Edwards' confidence in his own ability is implicitly acknowledged feeling "flattered at being asked". He spends time with "local councillors, key community leaders - people who make a difference." Such membership has benefits providing access to powerful policy makers such as dinner with the Secretary of State.

Representation: For Edwards, representation within each network varies within the LT network for example Edwards' representation is extensive he is the CEO representing the Trust in different arenas, embodying the successful leadership model recognising that his position at the "grass roots level" is useful in other networks where he symbolises the successful headteacher which in turn promulgates his agency:

"I was on the frontpage a couple of years back...their annual report...it was

a big piece which was great... they want me 'coz [sic] it gives them credibility to look at the grass roots, and I'm at the grass roots..." (NWI, $7 / 4 / 18)$.

Here, the sharing of resources and reciprocity is evident, but Edwards transfigures into a more prominent role in his other networks:

"I have the biggest contribution on the Board, I'm also their safeguarding officer." (at the Youth Connect Foundation), (NWI, 17/4/18).

With Edwards' consultancy projects now evolving overseas (Project East) his representativeness is extensive in four out of his five networks. This is linked to his 
mobility and the position he holds within each network. Edwards is always "on the move" visiting schools, appearing at gatherings, chairing New Start meetings, attending board meetings, representing his networks dynamically. For example, Edwards was invited by the City Council as a member of the presentation panel to promote the city in a bidding process. He recounts his involvement:

[Council Leader name] asked me, we had a minute and half pitch, I did education for ten local authorities and then afterwards we went to a restaurant... [the city] turned all the [traffic] lights to green because they can..3 minutes... [laughs] takes about half an hour normally, there were 150 people in there. The mayor and I were looking after three [executives]...

Edwards clearly enjoys his role "representing ten LAs," being part of an elite group: "I'm very well connected" naming his connections, cementing his importance.

Ties: Edwards' network ties vary from being integral, reciprocal or derivative which in turn reflect levels of trust within each network. As CEO, his ties are integral, reciprocal in his Youth Connect and New Start Foundation networks where levels of trust are high, this is because membership is either selective or controlled and where dialogue is explicit in deciding on resource sharing, and where participation is mutually beneficial. Ties in these networks are strong. Conversely in the State network ties are derivative, gaining value through the dependency of underlying other assets such as the position of the Regional Schools Commissioner $(\mathrm{RSC})^{2}$ or Head Teacher Boards (HTB) ${ }^{3}$. Where trust is low and where there is a perception of competition or lack of trust, for example in the State network, dialogic governance is problematic (and ties are weak) shown when Edwards describes the relationship between the HTB, the LT and the RSC: "they are not great for us" he tells me because ex-employees from the LT work for the RSC, and due to strict conflict of interest rules, decisions on school takeovers and school to school 
support are outsourced to another region hampering the process: "the decision making is shocking." Edwards gives the reason being:

... the competitive element within it...to be fair there are so many declarations of interest it gets passed around different boards, ...it's like we don't trust you." (NWI, 17/4/18).

Edwards identifies the failure of governance in the State network when the local HTB have to decide on school takeovers, such instances of failure are associated with the derivative weak ties and fluidity of membership.

Edwards' networks are carefully constructed: he is the "big hitter" with other "big hitters" he operates in these network spaces fully understanding his position and reciprocity that binds them together. However, Edwards' weak ties with the State network encouraged him to act: he disagreed with an LA policy on school admissions, he describes his reaction:

I decided... to make everyone sit up and think about it so the only way you can do that is to do something which appears to be quite radical... The DfE don't like that but they sent their top person down... (STR, 11/9/18).

Edwards' actions attracted national publicity - much of it negative, but "he was prepared to put his name to it," the visit from the DfE, resulted in “...the LA are under scrutiny now...so it worked." His insecurity over his position however is evident: "I might not agree with the policy... so I have to be careful," (NWI, 17/4/18).

Locus of Authority. Edwards' networks are vitally important to the success of the business, within two of his networks he is the hegemon (Goodwin, 2009). As Chair of New Start he jointly decides on grants awarded. These are usually joint projects supporting the creation of facilities for schools and local communities. Since its inception 
over $£ 1.3$ billion has been allocated nationally. Comparatively, his position within the State network is more hierarchically prescribed, with existence of hegemonic actors such as the RSC and HTB. This dilutes dialogic governance due to lower levels of trust. However, Edwards' association with "big hitters" legitimises his position and standing within his networks. He often features on television as the "go to" educational expert, he readily tells me of these exploits - affirming his agency. Edwards embodies the government policy of system leadership with his successful leadership of a MAT. As an authority on government policy he articulates the rationale behind policy within his networks responding to a question during an interview:
"The government policy has changed in that they have saved a significant amount of money by changing the academies programme, I think this is right, they are not allowing multi academy trusts to open schools in an area where schools are not very good because all that does is close down other schools. We have never done that, we don't believe in that." (BPI, 5/12/17)

Edwards is directly involved in speaking about, explaining, and justifying policy, giving policy pitches in both intimate and public arenas for example with new parents or as the keynote speaker at a DfE networking event. He meets with Ofsted who solicit his views and he appears before government Select Committees. He enjoys well publicised visits by various politicians and local councillors to his MAT. He was recently invited to House of Lords to promote his online learning product:

$$
\begin{aligned}
& \text { "I went to the Houses of Parliament, it was a primary thing... I pedalled our } \\
& \text { [online product] as I had the right people there; I'll do pedalling at that } \\
& \text { point." (NWI, 17/4/18). }
\end{aligned}
$$

Whilst Edwards is not the typical "boundary spanner" (Williams, 2002) transcending borders as a policy entrepreneur impacting global education networks, his 
work in framing and "selling" policy is developing abroad where the he is undertaking some lucrative consultative work on behalf of the Trust. The business of education interpenetrates Edwards' realist networks, specifically Youth Connect and its parent company who both utilise Edwards' educational expertise. Edwards describes the complex and interrelated nature of his networks and his role within them:

I can't be a sales person, but I open the doors, [company name] would not have bought it (LT online learning product) without me. The [company name] is next, and they have got more subsidiaries, they won't buy it without me. (NWI, 17/4/18).

Reciprocity amongst Edwards' networks is evident: "He [Communications Director of business] rings me up for favours, I would do him a favour - I'll talk to [professional sports person name]," depicting dialogic governance through negotiating and sharing resources.

\section{Realist networks as power structures}

Membership of networks are important for all actors as they are sites of power exchanges manifested in the differential distribution of resources (Krackhardt, 1990). Several of Edwards' networks "are productive" enabling him to facilitate (with the Trust directly benefiting) the distribution of resources. Power in this case is fundamentally enabling "where people gather together and act in concert," (Arendt, 1998 p. 244). Edwards' membership of his realist networks provides direct gains to the Lawrence Trust. These range from monetary contracts, sponsorship and expert knowledge. For example, through the Youth Connect network the LT has gained $£ 25,000$ in sports kit for LT staff as well as providing ongoing financial support for the provision of student fitness and wellbeing programmes. This contract through the Youth Connect parent company has been in place 
for over twenty-five years and is worth approximately $£ 100,000$ p.a. A trustee on the LT board who is Chief Executive of a PLC has agreed to jointly sponsor a new free school. Additionally, the LT and the business enjoy reciprocal marketing arrangements for example the business produces promotional films for the Trust, and Edwards promotes the PLC. The PLC has donated $£ 200,600$ as a "charitable educational contribution," although the LT was not specifically named, (Companies House (n.d.) website).

Similarly, Best Practice, a training provider pays a retainer ( $£ 35,000$ p.a.) to the LT to deliver leadership training in exchange for Edwards' leadership expertise shared at key promotional events. The exchange of expertise and specialist knowledge is manifest on the LT board which boasts a diverse range of influential corporate actors who provide important connections, membership to other networks and entrance into the market. For Edwards as chair of New Start he gains access to lucrative markets to sell online learning products. (to date the LT has sold $£ 100,000$ worth of business). Through New Start the LT has won several bids totalling £2milion for new facilities, ( $£ 700,000$ in 2016).

\section{Discussion: the importance of realist networks}

Identifying Edwards' networks is important because it provides a critical explanation of day to day operational, cultural practices that represent the nature of reality for a CEO of a MAT. These networks are "mechanisms of coordination" (Jessop, 2016). The dimensions of realist networks in table 1 help to identify the specific structure, characteristics and practices of Edwards' networks operating as modes of dialogic governance, dependent on a "continuing commitment to generate and share information" (Jessop, 2016 p. 169). Reading data shows that realist networks are responsive and rational where dialogue and negotiation over the goals of the network take place. The empirical data shows Edwards' long-term commitment to his networks revealing that he 
has access to influential groups both at government level, and those of the corporate world. They are non-competitive, and self-selecting, where resources are shared through joint localised projects. Importantly, "the analysis of relational aspects of human interaction can go beyond a metaphorical heuristic use of networks" (Christopoulos, 2008 p. 476) and through investigating Edwards "relational spaces" there is evidence that in three of Edwards' five networks ties are reciprocal or integral, information is shared, and trust high. As a "rhizomatic connector" (Rizvi \& Lingard, 2011) Edwards uses his network capital to "engender and sustain relations...which generates emotional, financial and practical benefit," (Urry, 2007 p. 198). At the micro level Edwards' entrepreneurial operations result in tangible benefits to the Trust (and often local communities) through the exchange of resources.

Edwards' realist networks are small and close-knit where actors know each other. He is selective and strategic when constructing networks: "I spend a lot of time working with local councillors, key community leaders, people who make a difference," where some are networks of influence (for example The State, Emerging Networks), others are networks of decision making (for example LT, New Start and Youth Connect). Not all networks have the same strength of ties: where ties are strong and integral then Edwards displays his agency through his decision-making capacity. Where ties are weak, and derivative, and where trust is low (e.g. The State network) then tension and possible conflict may be present relating to issues with policy, here the network may become factionalised, and where a hegemon may emerge to act as broker, (Christopoulos, 2008).

Edwards' realist networks are built on interdependencies where accountability is opaque, and boundaries are blurred where actors can be relationally entrepreneurial (Christopolous, 2006). As a corporate leader Edwards represents a distinct "edubusiness" (Mahony, Hextall, \& Menter, 2004) making profit and brokering deals. 
Edwards' project is nuanced where self-preservation and network membership are guarded, nurtured and heavily invested in. However, Edwards, as an anchor of neoliberalism, embodies the delivery of education services dispensed through a "mix of strategic alliances, joint working arrangements, networks, partnerships and other forms of collaboration..." (Williams, 2002 p. 102).

\section{Conclusion}

I use Edwards' case to identify and explain the practice of a particular CEO in his realist networks as "ethnographic accounts of networks are a rarity" (Rhodes, 2002 p. 412) and where "the study of networks, is inextricably bound up with interpreting the narratives on which they are based" (Rhodes, 2002 p. 401). Adopting an ethnographic single case presents "complex specificness" where the focus remains on Edwards and his story. Importantly the project has focussed on the single case enabling a sustained investigation into the practices of the CEO making a valuable contribution to understanding critical aspects of executive leadership practices. The project makes no generalisations about other CEOs because "a policy networked model may have a particular feature which applies only to a unique case," (Dowding, 2001 p. 97). There are limits to knowledge and knowing about networks: membership is fluid - changing over time, nonetheless what the study shows is that the interplay between the government and civic society is complex. For Edwards the network project is a lifelong work of labouring to construct and design realist networks beyond his organisation.

Whilst theoretical claims in the literatures are made with "the rise of networks heralding an emerging postmodern condition freed from the ossified hierarchies of the mid $20^{\text {th }}$ century," (Davies, 2011 p. 2) in reality networks must be seen in the wider socioorganisational context of management and regulation and because hegemony "is partial 
and precarious," and "hierarchy can never retreat into the shadows," (Davies, 2011 p. 5). Hierarchies exist as a mode of state control and power through and across networks, collaborations, and partnerships particularly where ties are weak and membership fluid. Whilst Edwards is operationally autonomous, comfortable in interacting with the market, brokering deals, judging funding bids, appearing on TV as the expert, he is controlled by the mechanisms of the state. He is called to appear before the Select Committee and Ofsted panels. He is required to "report back," on his activities at DfE networking events; his schools are still inspected, the pressures of performativity are clear "all the DfE care about are results" he says. His MAT is under direct control from central government. If performance targets decline Edwards' privileged membership of his highly valued networks could be affected. As long as he is "doing his job" through ensuring schools are effective and "in profit" then he able to pursue his own pet projects. His need for affirmation is considerable and his insecurity regarding the power of the state is articulated "I have to be careful" when he does speak out against policy, he utilises networks to defend his position, eventually achieving a rethink on admissions. He is cautious in answering questions on the DfE, RSC and HTB's role airing his frustrations with the system of declared interests and the slowness of decision making. He remains "on message" at DfE workshop events, staff recruitment days and parent meetings embodying the success of government policy. Edward's realist networks therefore are precarious and in some instances the network becomes his cage.

\section{Implications for further study}

This research matters because it identifies a new type of network that of the realist network through which dialogic governance operates at a local level. The realist network is "home-grown", inter-dependent, reflecting the everydayness of the practices of the 
CEO of a MAT. Being a member of realist networks is an important part of the MAT CEO role, which involves forming strategic alliances, increased collaboration, resource sharing, and enhancing entrepreneurialism. As a new form of school leader inhabiting a complex structure of a MAT, Edwards embodies the corporatisation of state education exogenously through his involvement with realist networks, the nature of ties and the practices of corporate actors in them, and endogenously through his praxis. Such research makes an important contribution to the field in its investigation and analysis of the emerging position of the CEO of a MAT, where little empirical research has been done. The research has critically examined a particular aspect of executive educational leadership as an example of "modernising" school leadership practice and in so doing calls for CEOs and their work to be investigated further perhaps undertaking a comparative study of CEOs and their practices in England with CEOs in other contexts for example school superintendents in the US.

\section{Notes}

1. Various terms for policy networks are used in policy science: partnerships, interactive governance, interactive policy making, policy community, issue networks. (Davies, 2011)

2. The Regional School Commissioners (RSCs) act on behalf of the Secretary of State for Education accountable to the National Schools Commissioner. They make decisions on academisation, underperforming academies and intervening in academies where governance is inadequate. (DfE 2018b)

3. Headteacher boards (HTBs) are responsible for advising and challenging RSCs on academy related decisions. (DfE, 2018b).

\section{References}

Agar, M. (1980). The Professional Stranger. New York: Academic Press. 
Altheide, D., \& Johnson, M. (1998). Criteria for assessing interpretative validity in qualitative research, in Denzin, N., \& Lincoln Y. (Eds.). Collecting and interpreting Qualitative Materials. (pp. 381-411). London: Sage.

Arendt, H. (1998). The Human Condition. Chicago: University of Chicago Press

Au, W., \& Ferrare J.J. (2015). Mapping Corporate Education Reform. New York: Routledge.

Ball, S.J., \& Junemann, C. (2012). Networks, New Governance and Education (Bristol: Policy Press.

Ball, S.J., Junemann, C., \& Santori, D. (2017). Edu.net: globalisation and education policy mobility (Abingdon: Routledge).

British Educational Research Association [BERA] (2018). Ethical Guidelines for Educational Research, (4th ed.). Available online at: https://www.bera.ac.uk/researchers-resources/publications/ethical-guidelines-foreducational-research-2018.

Börzel, T. (1998). Organising Babylon on the different conception of policy networks. Public Administration, 75(3), 253-273.

Coldron, J., Crawford, M., Jones, S., \& Simkins, T. (2014). The restructuring of schooling in England: the responses of well-positioned headteachers. Educational Management Administration and Leadership, 42(3), 38-403.

Christopoulos, D.C. (2008). The Governance of networks: heuristic or formal analysis? A reply to Rachel Parker. Political Studies, 56(2), 475-481.

Companies House (n.d.) Get information about a company. Retrieved from: https://www.gov.uk/get-information-about-a-company. (accessed August 2018).

Courtney, S.J. (2016). Corporatizing School Leadership through hysteresis. British Journal of Sociology of Education, 38(7), 1054-1067.

Courtney, S.J. (2015a). Corporatised leadership in English schools. Journal of Educational Administration and History, 47(3), 214-231.

Courtney, S.J. (2015b). Mapping School types in England. Oxford review of Education 41(9), 799-818.

Davies, J. (2011). Challenging government theory: from networks to hegemony. Bristol: Policy Press.

DfE (2010). The Importance of Teaching (Cm 7980), (London: TSO).

DfE (2016). Excellence Everywhere (Cm 9230), (London: HMSO).

DfE (2018a). Get information about schools Available online at: https://getinformation-schools.service.gov.uk (Accessed May 2018).

DfE (2018b). School Governance: School Commissioners group: Available at: https://www.gov.uk/government/organisations/schools-commissioners-group/about (Accessed December 2018).

Dowding, K. (2001). There must be an end to the confusion: policy networks intellectual fatigue and the need for political science methods courses in British universities. Political Studies, 49(1), 89-105.

Fitzgerald, T. (2012). Documents and documentary analysis. In Briggs, A.R., Coleman, M., \& Morrison, M. (Eds.). Research methods in educational leadership and management, (3 ${ }^{\text {rd }}$ ed.). (pp. 296-308.). London: Sage. 
Garcez, P. (2017). Micro-ethnography in the Classroom. In Hronberger, N.H. (Ed.), Encyclopaedia of language and education. (pp 257-271). Boston: Springer.

Geertz, C. (1973). The interpretation of cultures. New York: Basic Books.

Grace, G. (1995). School leadership. London: Falmer Press.

Granovetter, M.S. (1973) The strength of weak ties. American Journal of Sociology $78(6), 1360-1380$.

Goodwin, M. (2009). Which networks matter in education governance? A reply to Ball's new philanthropy, new networks and new governance in education. Political Studies, 57(3), 680-687.

Greany, T. (2018). Innovation is possible it's just not easy: improvement, innovation, and legitimacy in England's autonomous and accountable school system. Education Management Administration and Leadership, 46(1), 65-85.

Gunter, H.M., Hall, D., \& Apple, M. (Eds.). (2016). Corporate Elites and the Reform of Public Education. Bristol: Policy Press.

Gunter, H.M., \& Mills, C. (2017). Consultants and consultancy: the case of education. Cham Switzerland: Springer.

Hartley, D. (2018). Foreword. In Courtney, S.J., McGinity, R., \& Gunter, H.M. (Eds.). Educational Leadership, Theorising Professional Practice in Neoliberal Times, (pp. xvii-xxi). London: Routledge.

Hughes, B.C. (2019) Investigating the CEO of a MAT: Examining the position and practices on 'the street.' Educational Management Administration and Leadership. Advance online publication. doi:10.1177/1741143219833688

Hysing, E., \& Lundberg, E. (2016). Making governance networks more democratic: lessons from the Swedish governmental commissions. Critical Policy Studies, 10(1) 21-38.

Jessop, B. (2016). The State Past Present and Future. Cambridge: Polity Press.

Krackhardt, D. (1990). Assessing the political landscape: structure cognition and power in organisations. Administrative Science Quarterly, 35(2), 342-369.

Kulz, C. (2017) Factories for Learning. Manchester: University Press.

[Lawrence Trust] (n.d.) website pages. [Region]: Lawrence Trust. (accessed 20 June 2018)

McCann, E., \& Ward, K. (2012). Assembling urbanism: following policies "studying through" the sites and situations of policy making. Environment and Planning. 44(1),42-51.

Mahony, P., Hextall, I., \& Menter, I. (2004). Building dams in Jordan, assessing teachers in England: a case study in edu-business. Globalisation, Societies and Education. 2(2), 277-296.

National Governor's Association (2017). Welcome to a Multi Academy Trust 20162017. Birmingham: NGA.

Pierre, J. (2009). Reinventing governance reinventing democracy? Policy and Politics 37(4). 591-609.

Rhodes, R. A. W. (2002). Putting people back into networks. Australian Journal of Political Science, 37(3), 399-416.

Rhodes, R.A.W. (1997). Understanding governance. Maidenhead: OU. 
Rizvi, F. and Lingard, B. (2011). Social Equity and the assemblage of values in Australian higher education. Cambridge Journal of Education 41(1), 5-22.

Salokangas, M., \& Ainscow, M. (2018). Inside the Autonomous School, making sense of a global educational trend. London: Routledge.

Saltman, K.J. (2010). The Gift of Education: public education and venture philanthropy. New York: Palgrave Macmillan.

Spradley, J. (1980). Participant observation. New York: Holt, Reinhart and Winston.

Triantafillou, P. (2004). Addressing network governance through the concepts of governmentality and normalization. Administrative Theory and Praxis, 26(4), 489508 .

Tulowitzki, P. (2019). Shadowing school principals: what do we learn? Education, Management, Administration and Leadership, 47(1), 91-109.

Urry, J. (2003), Social networks travel and talk. British Journal of Sociology, 54(2), 155-175.

Van Maanen, J. (2011). Tales of the Field, (2nd ed.). Chicago: University Press.

Wolcott, H.F. (1995). The art of fieldwork. Walnut Creek Ca: Altamira.

Wolcott, H.F. (2003). The man in the principal's office, (updated edition). Walnut Creek Ca: Altamira.

West, A., \& Bailey, E. (2013). The development of the academies programme: "privatising" school-based education in England 1986-2013, British Journal of Educational Studies, 61(2), 137-159. doi: 10.1080/00071005.2013.789480.

Williams, P. (2002). The competent boundary spanner, Public Administration, 80(1), 103-124. 
Table 1. Dimensions of the realist network

\begin{tabular}{|c|c|}
\hline Structure & $\begin{array}{l}\text { Self-organised localised networks } \\
\text { Heterarchic rather than hierarchical }\end{array}$ \\
\hline Characteristics & $\begin{array}{l}\text { Reflexive } \\
\text { Consensual } \\
\text { Responsive } \\
\text { Interdependent } \\
\text { Rational } \\
\text { Pluralistic } \\
\text { Amorphous } \\
\text { Topographically confined }\end{array}$ \\
\hline Practice & $\begin{array}{l}\text { Dialogic (either tacit or explicit) to ensure approved outcomes whilst not } \\
\text { impacting others in the network. } \\
\text { Negotiating and redefining of goals in light of changing circumstances } \\
\text { Sharing resources and information } \\
\text { Participation in mutually beneficial joint projects } \\
\text { Locks in partners to the short, medium, long term decision-making } \\
\text { process to weaken opportunism. } \\
\text { Non-competitive. } \\
\text { Builds on interdependencies. } \\
\text { Membership is selective }\end{array}$ \\
\hline
\end{tabular}

(adapted from Jessop 2016 p.169). 
Table 2: Relational attributes of realist networks

\begin{tabular}{|l|l|l|l|l|}
\hline Network & Conditions of & Representation & Ties & Locus of \\
scope & Membership & & & authority \\
\hline Local & Selective & Extensive & Integral- strong & hegemonic \\
\hline Regional & Controlled/ & Limited & Reciprocal- & heterarchic \\
\hline National & Controlled/ & Extensive & Reciprocal- & hegemonic \\
\hline The State & fluid & & strong & \\
\hline Emerging & Selective & Extensive & Reciprocal- & heterarchic \\
\hline Unknown & open & Unknown & Indeterminate- & Unknown \\
networks & & & weak & hierarchic \\
\hline
\end{tabular}

(adapted from Christopoulos 2008) 